abundantly in the Black Sea and is very rich in iodine. Water containing the chopped alga is electrolysed at increasing potentials, iodine separating out at the lowest, then bromine and finally chlorine at the highest. The solution is then concentrated and further electrolysis yields mannite and alginates.

In the past mistakes have also been made by scientific workers in not paying sufficient attention to $(a)$ season of the year, (b) type of locality, (c) age of material, $(d)$ proportion of stipe to lamina in the sample. Here again the S.S.R.A. will, it is hoped, see that these gaps are adequately filled. If the kelp industry in a new form can be started again it should go far to improve the lot of the crofters in the Highlands and Isles of Scotland if their natural prejudices can be overcome. The poverty of these people has to be seen to be believed: the habitations compare unfavourably with many of our slums, and overcrowding in small, ill-lit and badly ventilated cottages with their heavy peat smoke atmosphere is the rule rather than the exception. Any effort, therefore, that will improve their lot is to be welcomed.

${ }^{1}$ Cauer, H., Biochem. Z., 299, 69 (1938).

"Stanford, E. C., J. Soc. Arts, 10, 185 (1862).

'Delf, E. M., Nature, 152, 149 (1943).

\section{GENETICS IN RELATION TO DISEASES OF ANIMALS AND PLANTS}

$A^{\mathrm{T}}$

$T$ a joint meeting of the Association of Applied Biologists and the Genetical Society, held in London on March 23, the problem of the "Genetic Relations of Plants and Animals to their Pests and Diseases" was discussed.

Dr. C. D. Darlington (president of the Genetical Society) opened the proceedings by emphasizing the two fundamental facts that all species of animals and plants vary genetically in their power of resistance to, or defence against, disease; and that all disease organisms vary genetically in their power and mode of attack, and in their resistance to our control methods. Variability is the rule rather than the exception or nature, but crop and stock improvement in the last fifty years had tended to reduce variability within the different cultivated races even to the extent of producing, at times, a homozygous pure line. One of the problems of the future must be to introduce new variation into the cultivated forms. $\mathrm{He}$ also discussed the power of plants to produce antibodies to a virus, and considered that the recent work of J. M. Wallace (J. Agric. Res., 69, 187) showed that antibodies to a virus are produced by tobacco and that they can propagate themselves in the tomato plant, which cannot itself develop them.

Dr. J. Hammond dealt with constitution in cattle in relation to pests and diseases, particularly as illustrated by the introduction of European cattle into the tropics. There they are particularly susceptible to local pests and diseases to which the native or other tropical cattle are comparatively resistant: European cattle have a higher level of tick infestation than the zebu, possibly due to their longer hair and higher body temperatures. There is no evidence of any immunity to tick fever in the zebu, but the resistance to its effects is much higher than in European races, and first crosses come much nearer to the zebu. Body temperature and respiration-rate have been measured in crosses and back-crosses between zebu and European cattle under tropical conditions. Milk production and growth run parallel with their resistance to tick fever, and there is little doubt that they are all dependent on differences in physiological constitution connected with heat regulation at high air temperatures. New tropical breedsfor example, the Santa Gertrudis and the Philaminare being formed to combine the productive powers of European beef cattle with the heat-, tick- and disease-resisting qualities of the zebu.

Michael Pease discussed the inheritance of disease resistance in poultry. He said that it had been claimed that the virtual disappearance of fowl paralysis in recent years had been due to selective breeding. In the Cambridge flock the disease was first noticed in 1930 ; increased to an alarming peak in 1935 ; and thereafter declined to negligible proportions in the war years. This was typical also of other parts of the country. In spite of this, analysis of the breeding results year by year gave no evidence that inheritance played any part in the incidence of the disease. With regard to non-specific disease in poultry it was widely held that this was due to breeding from too young birds. A statistical analysis of chick and adult mortality at Cambridge had shown that the determining factor was not the age of the mother, but whether she died during the breeding season or survived. Mothers which died early during the season left a progeny with an excessive death-rate. The age or death of the cock was without any apparent effect.

Dr. J. S. Carr discussed the heritable susceptibility to cancer in the domestic fowl. The incidence is high in all breeds throughout the world, and it is generally considered that the majority of cases are due to the action of carcinogenic viruses, of which a number are known. Using Rous No. 1 Serum as a test virus and 6-8-weok old chicks as host, it was possible to show that the main factor determining known growth was the genetic constitution of the host. From a flock of Brown leghorns it was found possible to build up by selection a line with very high resistance to this virus. The line was also resistant to other carcinogenic viruses and to a certain extent to chemically induced tumours.

Dr. William Black discussed the inheritance of resistance to blight (Phytophthora infestans) in the potato. A wild polyploid (Solanum demissum) was used as the source of resistant genes. Three strains of blight, $A, B$ and $C$, were isolated and four resistant phenotypes were differentiated as follows :

$$
\begin{aligned}
& \text { (1) Plants immune from } A, B \text { and } C \text {. } \\
& \text { (2) " " " " " }, A \text { and } B \text { but not from } C \text {. } \\
& \text { (3) } ", \quad \text { and } C \text { but not from } B \text {. } \\
& \text { (4) } ", \quad \text { but not from } B \text { and } C \text {. }
\end{aligned}
$$

As all these were immune from $A$ it appears that this strain is less virulent than the others, but the difference in virulence between $B$ and $C$ appeared to be qualitative rather than quantitative. A series of parallel tests of derivatives of three species, Solanum rybinii, $S$. demissum and $S$. tuberosa, led to the conclusion that immunity from $A$ and $B$ is controlled by two major genes, $R a$ and $R b$. Plants carrying $R a$ are immune from the $A$ strain, while plants carrying $R b$ are immune from both $A$ and $B$.

Dr. G. Cockerham discussed the genetical aspects of resistance to potato virus and particularly the problem of 'hyper-sensitiveness' which causes such rapid death of the tissues round the point of infection that the virus is unable to spread. This results in what he 
calls 'field immunity'. A single dominant gene $N x$ produces hyper-sensitiveness to several strains of virus $X$ but not to other aberrant strains. Another gene $\mathrm{Na}$ determines hyper-sensitiveness to virus $A$, and in each of six cultivated varieties this is closely linked with $N_{x}$. In the variety South-Esk, however, the two genes are independent. Still another gene $N_{c}$ determines hypersensitiveness to virus $C$ which is a strain of virus $Y$. No cultivated variety of potato is hypersensitive to virus $Y$, but five clones of three different 'wild' species showed characteristic responses when infected in the laboratory. Dr. Cockerham believes that 'hyper-sensitiveness' is a character of significant value in virus control.

Prof. T. J. Jenkin gave a short account of work in connexion with disease and pest resistance at the Welsh Plant Breeding Station at Aberystwyth, which is concerned chiefly with the production of new varieties of oats, clover and herbage grasses. By selection from mixed population a variety of oat, $S .75$, has been produced which is highly resistant to smut (Ustilago), and the white winter oat variety, $S .81$, is one of the most resistant to eelworm. In clover, special attention has been paid to finding strains resistant to clover rot (Sclerotina trifoliorum) and eelworm (Tylenchus devastatrix). Here the choice of breeding material is far wider than in oats owing to the heterogeneity of the crop and the heterozygosity of individual plants.

In the discussion which followed the principal speakers, Prof. W. J. B. Riddell directed attention to the effect of the different varieties of Pneumococcus causing pneumonia. In Glasgow, type II occurred with higher frequency than in Manchester, where type I was the most common: Since the introduction of chemotherapy, type II had relatively increased in Glasgow.

Dr. K. Mather mentioned the work of Lindstrom and his pupils on the bacterial wilt of maize. In this case the bacterium increases in virulence by passage through a resistant inbred line of maize, but decreases in virulence by passage through a susceptible line. In mixed inoculations the virulent strain is selectively favoured by resistant maize and the avirulent by susceptible lines.

M. A. Crane discussed the effect of the use of 'clonal' crops and suggested that some of the dangers might be avoided by the regular production of shortlived clones or by the regular production of $F_{1}$ families which are sufficiently uniform for commercial requirements. Virus infection upsets uniformity even in clonal crops. In some vegetatively produced plants the position has now been reached when as much care, or more, has to be given to the nursing of old clones as to their cultivation.

F. C. Bawden did not agree that present available evidence proved the existence of virus antibodies in plants.

Dr. H. W. Howard said that at Cambridge experiments had been carried out to obtain potatoes resistant to blight, using $S$. demissum as the source of immunity, with results very similar to those obtained by Dr. Black at Edinburgh. In $F_{6}$ and $F_{7}$, however, there was some indication of the effect of modifying genes being of importance. He considered that the genetics of the parasite ( $P$. infestans) needed more investigation. Strains from single spores had not changed their virulence and the origin of new strains may be due to sexual reproduction.

R. Stenton suggested that the ratio of diseased individuals in a mixed population of unknown genetic constitution might be found to be proportional to the number of recessives present.

Dr. C. B. Williams (president of the Association of Applied Biologists), in summing up, re-emphasized the importance of keeping a high level of variability in the host plants or animals as a protection against possible new diseases in the future. He gave a short account of work recently carried out by Dr. S. C. Harland in Peru on the selection of cotton. Harland started with a very large number of plants tested individually for a small number of commercially valuable characters, and selected for these only, leaving all other characters as variable as possible. $\mathrm{He}$ avoids all self-fertilization which produces a large proportion of homozygotes in all characters both visible and invisible.

\section{ARCHAOLOGICAL EXPLORATION IN SOUTH AFRICA}

CEVERAL interesting articles on archæological $\checkmark$ topics have been published recently in South Africa. Prof. van Riet Lowe and Prof. H. Breuil have been studying a number of Stone Age sites in southern Mozambique, not so far from Lourenço Marques $^{1,2}$. It is true that both reports are very much of an interim nature, and that, except for a page of pottery profiles in one of them, they are unillustrated; but they are important, for enough has been found to show that, archrologically speaking, the area is going to prove of very significant interest. Early palæolithic finds, including some of a Clacto-Abbevillian facies, occur along the foot-hills of the main mountain chain and in the river valleys. At the time when their makers were alive, it seems that the sea coast lay farther inland than it does to-day. Later Stone Age industries occur nearer the present shore-line.

Mr. B. D. Malan, of the Archæological Survey, has issued a handy little instruction pamphlet for the use of would-be excavators ${ }^{3}$. Of course, a pennyworth of practice under supervision is worth pounds of theory, but there is room for the latter, too. It is perhaps a pity that no 'tips' for studying rock-shelter paintings and rock carvings are given.

Prof. van Riet Lowe's notes on the laws in South Africa governing archæological and vertebrate palæontological research ${ }^{4}$ will be read with mixed feelings. On one hand, certain classes of sites are limited in number, and once spoiled by well-meaning but untrained amateur investigators their evidence is for ever lost. On the other hand, it is not too much to say that most of our archæological knowledge to-day has been due to the devoted efforts of amateurs in the past. Many an amateur excavator is as good, if not better, than his professional confrere. To have a paid job as a prehistorian, whether in a Government department or at a university or in a museum, does not thereby endow the holder with the attributes necessary for a really good observer in the field. If regulations are made too tight, the amateur's interest in the subject tends to flag and his intellectual energy to be transferred to other fields. As a result the subject ceases to attract the general public, and a 'hobby subject' needs public interest if it is to continue to progress. In South Africa, the law permits surface finds to be freely collected; but certain types of sites (sealed deposits) are taboo, and so is the "removal and export of vertebrate fossils", and many 